\title{
Research on Mode of Teaching Ability of English Education Majors
}

\author{
Yawen Liu \\ School of foreign languages, Quzhou University, Quzhou Zhejiang, 324000, China
}

\begin{abstract}
Keywords: English education major, Subject teaching, Training mode.
\end{abstract}
\begin{abstract}
English teaching ability development is an important part of pedagogical education and teaching reform, the basis for helping students to reach a high attainment level and improve learning and living quality, and the basic guarantee for the success of teaching reform. The deepening of course reform of basic education brings about severe challenges to pedagogical students in teaching ability. The specialized development of teacher makes teacher a more demanding profession. This paper discussed effective development patterns for improving teaching ability of English education majors, and offered suggestions on improving mode of teaching skill training of English education majors.
\end{abstract}

\section{Introduction}

As teaching profession changes from experience-based and randomization to specialization, many countries transform their demand for "a large number of" teachers into for "high-quality" teachers. Thus, English language teachers are required to have pedagogical content knowledge (PCK) (Shulman,1987) and special English teaching abilities such as identifiable language negotiation, interaction, error correction, listening comprehension teaching, reading teaching, writing teaching and spoken English teaching, etc. (Zou Weicheng, 2009) in addition to basic language knowledge and language competence; to master tacit knowledge integrating subject knowledge and teaching ability (Jack, C.Richards, 1998) and students cognitive strategies of advanced theory of inference in addition to teaching skills of fundamental theory of inference. Whether considering that new course reform and teacher specialization development make teacher a more demanding profession, or from perspective of the tough employment situation of pedagogical students, to figure out effective ways to promote pedagogical English majors' teaching ability development is the duty of every foreign language educator.

\section{Research Status at Home and Abroad}

\section{Research Status at Home}

From different perspectives, related domestic researches mainly focus on:

Research on Composition of English Teaching Ability. Domestic research on teaching ability started at the beginning of the 1980s, generally focusing on teacher's ability and quality, such as Teacher Studies, Teacher Quality Studies, Teacher's Cultivation, etc. As the educational strategic status got improved and pedagogical education specialization was determined, researches on teaching ability was further deepened, and some monographs were published, including Ability Structure of Teacher, On Ability of Chinese Teacher, Teaching Ability Training Orientation, etc. The research on English teaching ability started to rise in the middle period of 1990s, but the research results are scattered on some periodicals and journals and most of them focus on subject teaching knowledge of English teachers, ability composition, quality of excellent English teachers, factors influencing teaching ability, teachers' decision and belief as well as course setting. In 1990, Prof. Han Gang from Hainan Normal University described the fundamental elements of foreign language teaching ability as follows: fundamental foreign language ability, teaching creation ability and classroom practice ability. In 2002, Xia Jimei conducted literature search in quantity and drew such conclusion that, teaching ability of English teachers should include foreign language education knowledge and view, and foreign language teaching ability and research ability. On this basis, Professors Dai Manchun and 
Zhang Xichun indicated in 2004 that, "foreign language teachers should own solid basic knowledge, understand educational theory and know students' mentality and the rule of second language acquisition as well as Chinese and Western culture, and have strong capacity for scientific research etc."

In 1995, Wu Zongjie introduced action research in foreign language circle in China the first time, and took Comprehensive English as the breakthrough to conduct bold RICH mode reform. He gained good effects through trying "research-based study", "integrated course”, "collaborative learning”, "overall improvement of humanistic quality" and "teachers' self-development”. Besides, action research mode of Prof. Zhi Yongbi from School of Foreign Languages in Nanjing Normal University also reaches the purpose that "education action research towards cooperation not just makes teachers' professional quality improves comprehensively, but also makes teachers experience teaching joys and creation joys and makes teachers gain internal dignity and pleasure due to creation”. In 2004, Wu Xin carried out two-year follow-up research on the changes of backbone English teachers in the period of participation in the training and after they participated in the training. The research shows that existing knowledge-transference teacher training has no significant influence on the development of teaching ability. Wu Zongjie (2004) critically interpreted the issue about the speaking right of teacher's development and disclosed the form of restraining autonomous development - classroom and school interaction mode. "Quasi-research-based English teacher training mode" was tried by Prof. Guo Cuilian from Wuyi University for English teaching course reform. She improved teaching ability of normal university students through repeated cycle of “explanation” - “demonstration”. “observation” - "practice” and guide” - "introspection” "explanation". This test result shows that it is feasible to train quasi-research-based teachers which adapts new course reform with the reflective mode, and the effect is good and stable (Guo Cuilian, 2008).

\section{Research Status Abroad}

\section{Research on Composition of Teaching Ability}

The research on the composition of teaching ability is the research hotspot of foreign experts and scholars. Different experts hold different views due to their different focuses, as shown in Fig.1.

\begin{tabular}{|c|c|}
\hline Researcher & Structure of teaching ability \\
\hline Shulman,1987 & $\begin{array}{c}\text { 1. Classroom organization and management; } 2 \text {. clearly explanation and vivid } \\
\text { description; 3. arrange and check tasks; 4. effectively interact with students through } \\
\text { question asking, exploration, praising and criticizing }\end{array}$ \\
\hline Josep M.Cots, 2005 & $\begin{array}{l}\text { 1. Language competence (including linguistics ability) and communicative } \\
\text { competence; } 2 \text {. teaching ability }\end{array}$ \\
\hline Andrews, 1999 & $\begin{array}{l}\text { 1. Ability to handle language-related problems; } 2 \text {. self-development ability; } 3 . \\
\text { reflective ability; } 4 \text {. ability to cognize students }\end{array}$ \\
\hline Toledo list,1983 & $\begin{array}{l}\text { 1. Ability to plan teaching at different cognition level; } 2 \text {. ability to state students' } \\
\text { results with terms; } 3 \text {. differentiate and evaluate students' ability to learn problems; } 4 . \\
\text { ability to organize and use proper teaching; } 5 \text {. ability to apply different teaching } \\
\text { strategies; } 6 \text {. ability to apply similar or different exploration strategies; } 7 \text {. ability to } \\
\text { transform in different teaching; } 8 \text {. ability to adjust teaching behavior so as to adapt } \\
\text { learners; } 9 \text {. ability to communicate with individuals, small groups and large groups; } 10 . \\
\text { ability to express subject knowledge }\end{array}$ \\
\hline Ray.H.Simpson,1966 & $\begin{array}{l}\text { 1. Ability to impart knowledge; } 2 \text {. ability to organize teaching; 3. ability to handle } \\
\text { interpersonal relationship }\end{array}$ \\
\hline $\begin{array}{c}\text { Renfro C. } \\
\text { Manning,1983 }\end{array}$ & $\begin{array}{l}\text { 1. Ability to formulate teaching plan; 2. teaching activity ability; 3. classroom } \\
\text { management ability; 4. knowledge transfer ability }\end{array}$ \\
\hline Annelies Gills & 1. Professional attitude; 2. teaching ability; 3. subject ability \\
\hline
\end{tabular}

Over the 20 years, international pedagogical education field gradually has formed a series of mainstream English teaching ability training modes. They play an obvious invigorating role in higher teacher education, including the following training modes. 1) Problem-based Learning Mode. It originated from American medical education in 1950s, and later is was expanded to each field of education. It requires students to solve a practical problem in the form of group. During solving the problem, students' practical ability improves. 2) School-based Teacher-Education. In order to 
develop teaching practice ability of normal university students, many normal schools establish partnership with middle and primary schools, and regularly organize normal university students to participate in teaching practice in the partner schools. This is "specialty development school" mode in America, and this is "partner school" mode in Britain. 3) Simulation practice. Under specific conditions, normal university students combine theory study and carry out semi-independent teaching practice in time under the guidance of teachers. Such mode is an effective approach for normal university students to enter the role of teacher fast. 4) Microteaching. It was created by Stanford University. It is a practical teaching method which trains teachers' teaching skills with modern teaching technology. Now, it has influenced pedagogical education in the world. 5) Reflective practice. Symbolic research achievement of such mode is reflective practice mode for foreign language teachers which was proposed by Wallace(1991). Later, the research on teaching ability development mode grew vigorously.

The above researches not just indicate directions for follow-up study, but also lays a foundation for constructing new mode to develop English teaching ability of normal university students.

\section{Composition Elements of Teaching Ability of English Education Majors}

Based on domestic and overseas research results, Questionnaire on Qualification of English Teachers Before Employment prepared by Wang Qiang et al. and Survey on Specialized Knowledge and Technology of English Education Graduates prepared by Han Gang, this research formulates “Teaching Ability Questionnaire of English Education Majors". Through investigation of 100 students majoring in English education, the current situation of teaching ability of English education majors and the defects of teaching ability mode of English education majors are found. Acceding to the above research, composition element chart of teaching ability of English education majors are preliminarily constructed, as shown in Fig.2.

\section{Construction of Teaching Ability Training Mode of English Education Majors}

Based on talent training scheme of English education majors, teaching ability training mode of English education majors should own the following features. 1) Time completeness. This mode is implemented from the first day when students are admitted to the university, and covers the whole process in the university. Meanwhile, time arrangement reflects certain continuity and progressivity features. 2) Content comprehensiveness. The goal of this mode is to train students to become qualified teachers and grasp specialized knowledge, educational theory, vocational skills, teacher's ethics and scientific research for education. 3) Form diversity. This mode includes teacher's basic skill training, knowing well middle school environment, extracurricular activity practice, participation-based teaching practice, education practice, educational survey, social practice, simulation teaching, teaching practice and educational practice etc. Group training, large class competition and skill contest for English education majors etc. are adopted. 4) Teacher's ethics and skills are uniform. Firstly, this mode carries out ideological education when they enter the university. Secondly, subtle education about teacher's ethics is conducted for students through educational practice. Thirdly, teacher's ethics training is intensified through praising excellent students in skill competitions. 5) Theory and practice are unified. Educational practice course should be set together with educational theory course, including writing, oral English, speech and calligraphy etc. Except practicing basic skills in the university, students should be organized to go out the university and carry out teaching practice in middle and primary schools, including knowing well school conditions, guiding students to carry out activities, working as the teaching assistant, listening to the teacher in class and practice etc. 6) On-campus and off-company are unified. On-campus practice mainly involves basic skill training, course preparation and practice simulation etc. Off-campus practice mainly includes teaching assistant in middle and primary schools, participation-based teaching practice, practice and internship etc. Through survey and repeated practice, the author constructs teaching ability training mode of English education majors, as follows:

Conventional professional teaching skills of teachers, students' activities skill context for English education majors, foreign language and culture festival, and students with excellent spoken language 
etc.)

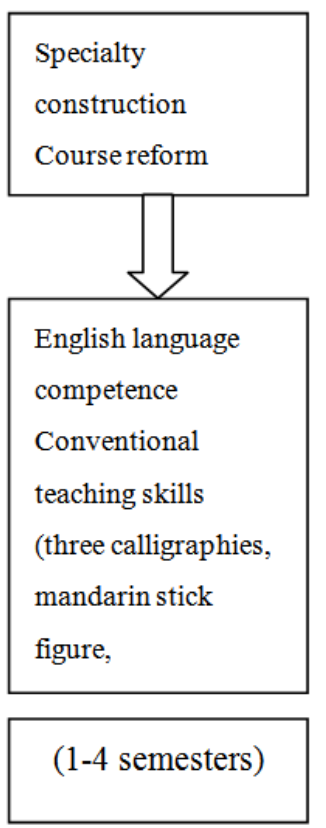

Classroom teaching reform simulated training

Teaching view, lecture and practice

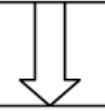

Classroom teaching implementation ability

(teaching design ability,

teaching resource organization and development ability etc.)

Teaching evaluation ability

(evaluation idea, evaluation

strategy)

Scientific research innovation

ability (teaching research

awareness, pedagogical tact)

\section{(5-6 semesters)}

Graduation thesis

teaching practice

Simulation classroom

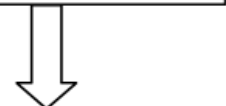

Classroom teaching

implementation ability

(teaching strategy,

classroom control ability,

class management ability)

Teaching reflection ability

Teaching research ability

(7-8 semesters)

Fig.1. Teaching ability training mode chart of English education majors

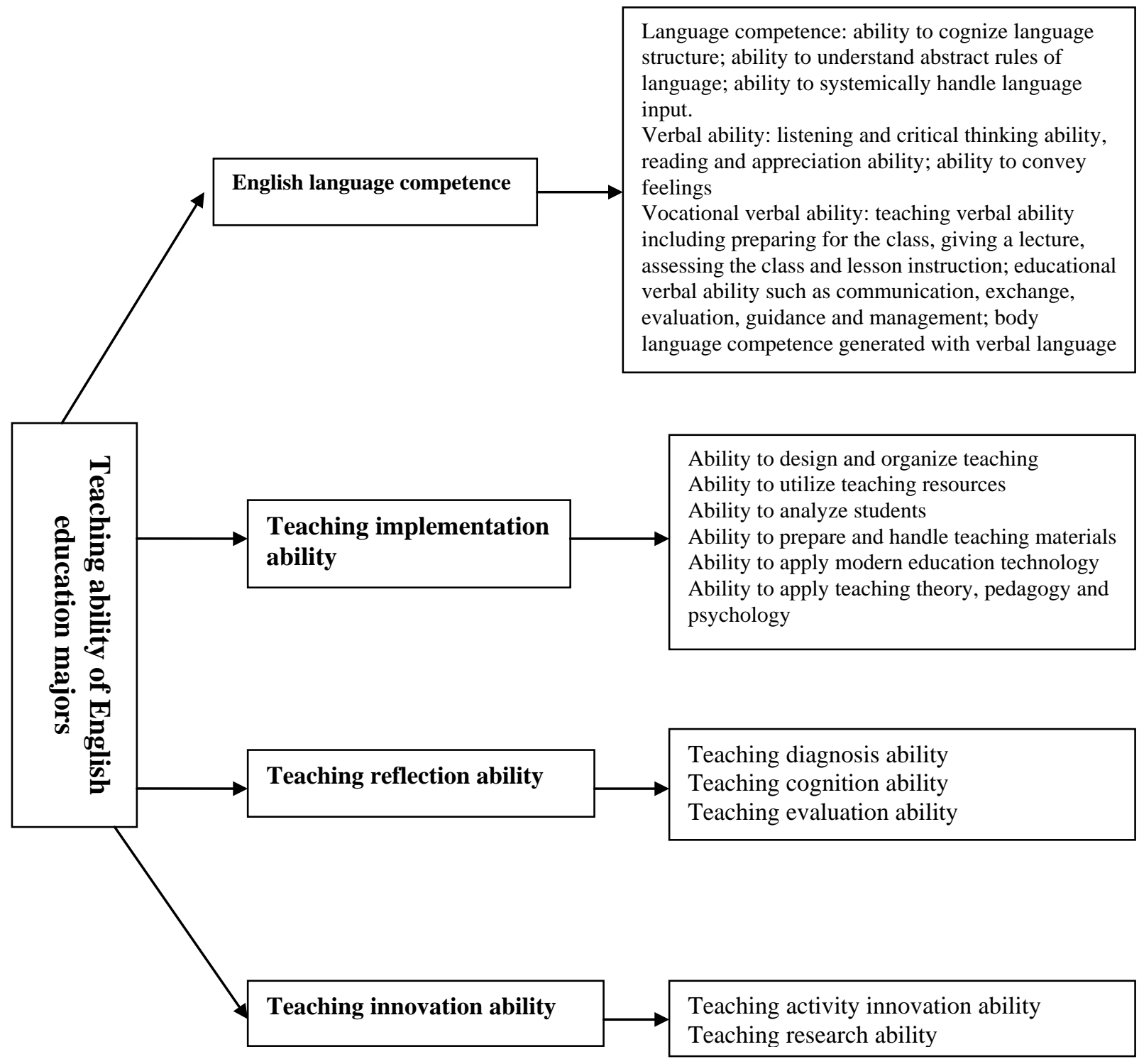

Fig.2. Composition element chart of teaching ability of English education majors 


\section{Acknowledgments}

This paper is educational science planning topic of Zhejiang Province in 2016. Project No.: 2016SCG131. It is subsidized by key subject construction fund of Quzhou University.

\section{References}

[1] Burns, R. W. Competency-based Education, New Jersey: Educational Technology Publication, Englewood Cliffs, 1972.

[2] Roberts, J. Language Teacher Education, London: Blackwell, 1998.

[3] Fu Anquan. On re-conceptualization of English teacher specialty development, Foreign Language World, 2009,1.

[4] Gu Peiya. Theory, research and practice of foreign language teacher education and development, Foreign Language Learning Theory and Practice, 2008, 3.

[5] Han gang, Li Qing. Educational course reform of English education majors: “3DR” course scheme, Journal of Hainan Normal University, 2005. 1. 